\title{
Medību tiesiskais regulējums medību drošības un sabiedrības interešu aspektā
}

\author{
Inga Kudeikina \\ Rìgas Stradiṇa universitāte, Juridiskā fakultāte, \\ Tiesību zinātñu katedra, Latvija \\ inga.kudeikina@rsu.lv
}

\section{Kopsavilkums}

Medības jau sen vairs nav nepieciešamas, lai izdzīvotu, tomēr tās ieñem stabilu vietu sociālajā dzīvē. Pēc Latvijas Mednieku asociācijas datiem Latvijā ir ap 25000 mednieku, kuriem medības ir svarīgs un nozīmīgs nodarbošanās veids, dzīves un pasaules uztvere [1]. Cilvēku piedalǐšanās medībās ir viens no individuālās pašrealizācijas veidiem, kura pamatā nav peḷnas gūšana. Secināms, ka medības pēc juridiskā satura nav komercdarbỉba [2]. Jāpiebilst, ka šì nav vienīgā medību izpratne. Dabas zinātṇu pētnieki uz medībām raugās no cita skatupunkta, galvenokārt vērtējot to devumu tautsaimniecībai (medījuma gaḷas vērtība, kažokādu vērtība, ien̦ēmumi par medību atḷaujām u. c.) [3], tādējādi uzsverot to saimniecisko pienesumu.

Neraugoties uz medību privāttiesisko raksturu, medību tiesiskā regulējuma nepieciešamība ir saistìta ar vairākiem aspektiem, tostarp ar sabiedrības interešu ievērošanu. Pirmkārt, medības ir saistìtas ar paaugstinātu bīstamību, jo tajās tiek izmantoti medību šaujamieroči un speciāli rīki, kas prasa noteikt īpašas prasības drošībai. Otrkārt, tās ir saistītas ar iejaukšanos faunā, dabā eksistējošā dabiskā līdzsvara ietekmēšanu, kas nozīmē nepieciešamỉbu pēc medỉbu norises vietas, laika, līdzekḷu un medījamo dzīvnieku izvēles normatīvas regulēšanas. Nepieciešamība saglabāt un aizsargāt medījamo dzīvnieku sugas tika uzsvērta arī, izstrādājot un pieṇemot 2003. gadā jaunu Medību likumu [4]. Praksē vērojamas tiesiskā regulējuma piemērošanas problēmas, kas saistītas ar tiesību normu interpretāciju vai izriet no dažu jautājumu nepilnīgas noregulēšanas. Tiesību zinātnieki nav pievērsuši pienācīgu uzmanību medību tiesisko attiecību problemātikas izpētei.

Atslēgvārdi: medības, medību drošība, medību noteikumi, mednieka apliecība. 
Inga Kudeikina. Medību tiesiskais regulējums medību drošības un sabiedrības interešu aspektā

Raksta mērķis ir izanalizēt medību tiesisko regulējumu divos sabiedrībai būtiskos aspektos - medību drošîba un sabiedrības intereses vides aizsardzībā saistībā ar medībām.

Materiāls un metodes. Pētāmā objekta struktūras noskaidrošanai un mērḳa sasniegšanai izmantota analīze. Iegūtie rezultāti ir novērtēti, izmantojot logisko metodi, savukārt tiesību normas analizētas, izmantojot tiesību normu interpretācijas metodi.

Kādi tiesību principi ir medību tiesiskā regulējuma pamatā? Medību pamatjautājumu tiesiskais regulējums ir noteikts Medību likumā [5]. Tajā ir formulēts likuma mērḳis - reglamentēt medību saimniecības pamatnoteikumus. Jau no definētā mērḳa un arī no likuma turpmākā teksta ir redzams, ka tiesību normas regulē ar medību norisi saistītus praktiskus jautājumus, mazāk pievēršoties medību kā tiesību institūta teorētiskam apskatam. Likumā nav definēti medību pamatprincipi. Šis fakts ir vērtējams kā tiesību akta trūkums, kas neḷauj skaidri novilkt robežas tiem pamatpienākumiem, kas tiesību subjektiem jāievēro, uzturot medību saimniecības un organizējot medības, lai nodrošinātu savu privāto interešu samērīgumu ar sabiedrības interesēm un vajadzībām.

Medību likuma izpratnē medības ir "darbību kopums vai atsevišḳas darbības, kad, izmantojot medību šaujamieročus, rīkus vai paṇēmienus, tiek izsekoti vai meklēti, kerti, sagūstîti, ievainoti vai nonāvēti medījamie dzīvnieki" [5]. Medības ir definētas kā process, tiesību norma nesatur medību materiāltiesisko raksturojumu. To var gūt, interpretējot tiesību normu. Medību legitimitāti nosaka šādi apstākḷi:

- medības var izpausties kā komplekss pasākums, kas sastāv no vairākām darbībām (medījamo dzīvnieku piebarošana, izsekošana un nonāvēšana) vai kā atsevišḳa darbība;

- medībās var tikt izmantoti tikai medību šaujamieroči, rīki vai paṇēmieni;

- medījamie dzīvnieki var tikt izsekoti, meklēti, k̦erti, sagūstìti, ievainoti vai nonāvēti.

Pazīmju uzskaitỉjums ir izsmel̦ošs un nav papildināms. Tādējādi par nelikumīgām tiks atzītas, piemēram, medības, kurās izmantots militārais šaujamierocis.

Jāatzīst, ka medības kā procesu un ar to saistìtās prasības vienā tiesību normā aptvert nevar. Tādējādi minētā tiesību norma pilnībā neatspoguḷo visas prasības, ko likumdevējs izvirza medībām un medniekiem. Lai medības būtu likumīgas, nepieciešams ievērot arī prasības par medījamo dzīvnieku sugām, medību termiṇiem, medību teritorijām un mednieka tiesisko statusu. Šos jautājumus regulē Latvijas Republikas Ministru kabineta 2014. gada 22. jūlija noteikumi Nr. 421 "Medību noteikumi", kas stājās spēkā 2014. gada 1. augustā. Medību likumību nosaka to atbilstība visiem šo jomu reglamentējošiem tiesību aktiem. Medību tiesiskais regulējums ir izkliedēts vairākos tiesību aktos, kas vērtējams kritiski, jo traucē tiesisko regulējumu aplūkot kā vienu veselu. Savukārt citu valstu tiesību sistēmās tiesiskais regulējums ir apkopots un ietverts kodeksā [6]. 
Medībās ir primāri tieši drošības jautājumi. Tajās ir jānodrošina mednieku, trešo personu un nemedījamo dzīvnieku drošība, maksimāli nepiel̦aujot ievainojumu vai nogalināšanas iespēju. Mednieku pienākumi nav izteikti atsevišḳa tiesību normā, bet nosakāmi, aplūkojot vairākas tiesību normas to kopsakarībā. Drošības pasākumi medībās tiek organizēti vairākos veidos, kas savstarpēji veido vienotu kompleksu.

Pirmkārt, viens no drošības pasākumu īstenošanas instrumentiem ir speciālu prasību izvirzišana personām, kas vēlas nodarboties ar medībām. Mednieks ir speciālais tiesību subjekts, kas tiesību aktos noteiktajā kārtībā ir ieguvis mednieka apliecību, t. i., apliecinājis savas teorētiskās un praktiskās zināšanas medību jomā. Saskaṇā ar Medību likuma 12. pantu "mednieka apliecība ir dokuments, kas nepieciešams, lai saṇemtu medību aț̣auju, mednieka sezonas karti un medību šaujamieroča iegādes atḷauju, kā arī drīkstētu medìt šajā likumā un citos medības reglamentējošajos normatĩvajos aktos noteiktajā kārtībā" [5]. Tātad mednieka apliecība ir mednieka statusu apliecinošs dokuments, kas nepieciešams, lai persona varētu nodarboties ar medībām, un vienlaikus ar šì dokumenta saṇemšanu persona iegūst tiesību aktos noteiktos mednieka pienākumus.

Mednieku un mednieku vadītāju eksamināciju veic Zemkopības ministrijas padotībā esošais Valsts meža dienests. Teorētiskās un praktiskās apmācības tēmas nosaka Latvijas Republikas Ministru kabineta 2014. gada 23. septembra noteikumi Nr. 567 "Noteikumi par mednieku un medỉbu vadìtāju apmācību un eksamināciju, kā arī medību dokumentu izsniegšanu un anulēšanu", kas stājās spēkā 2015. gada 1. jūlijā.

Kā trūkums vērtējams fakts, ka tiesību aktos nav noteiktas vispārējās prasības personām, kas vēlas kḷūt par mednieku. Mednieka statusa iegūšana ir saistīta ar speciālo zināšanu - medījamo dzīvnieku biologiija, anatomija, fiziologiija, uzvedỉba un slimības, medību organizēšana, medību veidi un pañēmieni, drošības prasības medībās - iegūšanu un demonstrāciju, bet netiek vērtētas pretendenta personiskās kvalitātes: rīcībspēja, veselība, tostarp garīgà veselība un psihoemocionālā noturība, kā arī pretendenta vecums. Jāpiebilst, ka īpašas prasības noteiktas gadījumos, ja mednieks vēlas iegūt medību šaujamieroci. Saskaṇā ar Medību likuma 13. panta pirmo daļu medīt ar medību šaujamieročiem drīkst mednieki, kuriem ir Valsts policijas iestādes izsniegta medību šaujamieroča glabāšanas atḷauja. Tādējādi medniekiem izvirzītās prasības tiek diferencētas atkarībā no tā, vai mednieks izmanto medībās šaujamieroci vai ne. Stingrākas prasības tiek izvirzìtas medniekiem, kuri vēlas saṇemt medību šaujamieroča glabāšanas atḷauju, jo uz viņiem ir attiecināmas Ieroču un speciālo līdzekḷu aprites likuma [7] prasības. Uz medỉbu šaujamieroča atḷauju var pretendēt persona, kas ir vismaz 21 gadu veca un kura ir saṇēmusi mednieka apliecību. Turklāt tiesību subjektiem ir noteikti papildu ierobežojumi, nosakot personu kategorijas, kuras nedrīkst saṇemt šaujamieroču vai lielas enerǵijas pneimatisko ieroču iegādāšanās, glabāšanas, nēsāšanas vai kolekcijas aț̣auju. To nosaka Ieroču un speciālo lïdzekḷu aprites likuma 17. pants. Tātad tiesības uz šaujamieroci ir tas papildu filtrs, 
Inga Kudeikina. Medību tiesiskais regulējums medību drošības un sabiedrības interešu aspektā

kas nošḳir personas, kuru iepriekšejjā vai pašreizējā sociālā uzvedība vai veselības stāvoklis izraisa pamatotas šaubas par viṇu labticīgumu un godprātīgumu. Pieṇemot, ka visi mednieki medībās izmanto medỉbu šaujamieročus, varētu secināt, ka Ieroču un speciālo līdzeklı aprites likuma prasības ir pietiekams veids, kā nodrošināt mednieku atlasi. Tomēr šāds secinājums vērtējams kritiski, jo medībās bez medību šaujamieročiem pastāv iespēja izmantot citus pietiekami bīstamus ieročus un rīkus, piemēram, nažus, ar kuriem var tikt nodarīts kaitējums citām personām. Turklāt jāṇem vērā, ka apdraudēts var tikt arī pats mednieks, piemēram, tam var uzbrukt meža dzīvnieks. Lai izvairītos no uzbrukuma vai to atvairītu, būtisks ir mednieka veselības stāvoklis. Ievērojot minēto, lietderīgi būtu Medību likumā paredzēt stingrākas prasības attiecībā uz mednieku personību raksturojošām pazīmēm, kā arī vecumu un veselības stāvokli. İpaši tas uzsverams kontekstā ar mednieka pienākumu būt personīgi atbildīgam par drošības prasību un medības reglamentējošo normatīvo aktu prasību ievērošanu medībās [8].

Otrs drošỉbas pasākumu komplekss ir saistīts ar medību procesa norisi. Prasības, kas ievērojamas medībās, ir noteiktas Medību noteikumos [8]. Tās var klasificēt kā vispārīgus noteikumus, kas jāievēro jebkurās medībās, un kā papildu nosacījumus, kas jāievēro īpaša veida medībās, piemēram, dzinējmedībās, ūdensputnu medībās. Tātad medỉbu organizācija ir atkarīga no medību veida. Par medību organizāciju atbildīgs ir medību vadītājs. Paaugstinātas prasības pret medību vadìtāju ir noteiktas dzinējmedībās, kur medību vadītājs var būt persona, kas ir saṇēmusi medību vadìtāja apliecību, tātad ir guvusi noteiktas zināšanas un prasmes medību vadǐšanā. Dzinējmedībās medību vadītājam ir noteikti konkrēti pienākumi, tostarp nodrošināt medību organizāciju un norisi, saṇemt un aizpildìt medību dokumentāciju, noteikt medību sākuma laiku, beigu laiku un medību pārtraukumus, zināt medību iecirkṇa robežas. Turklāt viṇam ir dotas plašas pilnvaras - noteikt medībās izmantojamo ieroču, munīcijas un šḳirnes medību suṇu izmantošanas ierobežojumus, pārbaudīt medību dalībnieku medību dokumentus un medību ieročus, pārtraukt medības vai aizliegt tās turpināt konkrētiem medību dalïbniekiem, pārtraukt vai aizliegt medības sliktas redzamības apstākḷos un vētras laikā, noteikt medījuma un medību trofeju piederību [8]. Prasības par paaugstinātu medību vadītāja kvalifikāciju dzinējmedībās ir samērojamas ar viṇa tiesībām un pienākumiem medību laikā. Lai arī Medību noteikumos nav paredzēta atbildība par nepakḷaušanos medību vadìtāja rīkojumiem, tas nenozīmē, ka medỉbu vadītāja tiesībām un prasībām ir tikai deklaratīvs raksturs. Atbildība par medību noteikumu neievērošanu noteikta Administratīvo pārkāpumu kodeksa 80. pantā [9], kā arī Krimināllikuma 112. pantā [10]. Medību vadītāja rīkojumu neizpilde vai nepaklaušanās viṇam traktējama kā medību noteikumu pārkāpums.

Kopumā drošības noteikumi vērtējami pozitīvi, tomēr daži aspekti izraisa kritiskas piezīmes. Tā, piemēram, Medību noteikumu 68. punkts nosaka, ka "dzinējmedībās aizliegts piedalīties medību dalībniekiem, kuriem nav spilgtas krāsas apgeērba vai viegli pamanāmu spilgtas krāsas apgeērba elementu, kas no jebkura skatu 
Inga Kudeikina. Medību tiesiskais regulējums medību drošības un sabiedrības interešu aspektā

punkta izceḷas uz apkārtnes fona" [8]. Krāsu uztvere un izpratne par spilgtu krāsu dažādām personām var būt atškiringa. To apliecina arī termina "spilgts" skaidrojums - tāds, kas izraisa redzes analizatorā samērā stipru kairinājumu [11]. Tāpēc nevar runāt par vienas noteiktas krāsas apgéreba vai tā elementu izmantošanu, bet katrs individuāli ir tiesīgs izmantot apgeērbu tādā krāsā, kas atbilst nēsātāja izpratnei par spilgtu krāsu. Prasība izmantot vienotu krāsu apgeērbā vai tā elementos palīdzētu novērst dažādas interpretācijas. Citu valstu pieredze rāda, ka tiesību aktā tiek noteikts precīzs apgēerba elementu uzskaitijums, piemēram, galvassega, veste vai virsjaka, kas ir oranžā krāsā [6].

Dal̦a prasību un aizliegumu ir jābūtības formā, bez reāliem kontroles mehānismiem, kas tādējādi prasību izpildi atstāj pašu mednieku ziṇā. Piemēram, katram medniekam, atrodoties norādītajā vietā, jāzina mednieku līnijas izvietošanas virziens un blakusesošo mednieku atrašanās vietas, vai - atḷauts šaut tikai sektorā, kas nepārsniedz 70 grādu uz abām pusēm no perpendikula pret mednieku līniju mastā vai ārpus masta. Aizliegta šaušana pa mednieku līniju - lādiṇ̌š vai tā dạ̦a nedrīkst lidot tuvāk par 15 metriem no mednieka. Neatbildēts ir jautājums, kā gūt pārliecību, ka konkrētais mednieks ir iepazinies un atceras pārējo mednieku atrašanās vietas, ka prot aprēkināt šaušanas sektoru un lodes lidojuma trajektoriju. Lielā mērā Medību noteikumu prasību precīza izpilde ir saistīta ne tikai ar tiesību indivīda likumpaklausību, bet arī ar spēju tās faktiski izpildìt, kas savukārt saistīta ar mednieka zināšanām un pieredzi. Par to, ka starp jābūtību un faktiskajiem apstākḷiem nedrīkst likt vienlīdzības zīmi, liecina šāds tiesu prakses gadījums [12]: nelimitēto medījamo dzīvnieku medību laikā nomedīts viens un sašauts viens nemedỉjamais dzīvnieks - medỉbu šḳirnes suns labradors-retrīvers, pārkāpjot Medību likuma 3. panta pirmās daḷas prasības, par ko medniekam uzlikts administratīvais sods, kas pārsūdzēts tiesā, jo mednieks administratīvā pārkāpuma izdarīšanu neatzina. Paskaidrojumos tiesai mednieks norādỉja, ka Latvijas Republikas tiesību aktos nav noteiktas medỉbu suṇu šḳirnes un vin̦š nav zinājis, ka labradors-retrīvers ir medību suns. Kā izriet no tiesas sprieduma, suṇa piederību noteiktai šķirnei nenosaka normatīvie akti, bet gan šḳirnes izveidošanas mērḳis. Medību suns ir suns, kas pieder šḳirnei, kas izveidota izmantošanai medībās. Pārbaudot lietā esošos pierādījumus, tostarp Latvijas Kinologiiskās federācijas izziṇas, tiesa atzina, ka labradors-retrīvers ir medību suṇu škirne, tātad administratīvais sods uzlikts pamatoti.

Tiesas sprieduma analīze pierāda, ka medniekam ir būtiski ne tikai formāli zināt tiesību aktu prasības, bet arī izprast to būtību un prast zināšanas pielietot praksē. Tiesību pārkāpumu nav pamata attaisnot ar mednieka zināšanu apjomu par tiesiskajiem vai faktiskajiem apstākḷiem un viṇa veikto situācijas analīzi, tā neiespaido tiesību pārkāpuma faktisko sastāvu. Tādēl, lai mazinātu gadījumus, kad mednieks izdara tiesību pārkāpumu, nepareizi novērtējot lietas faktiskos apstākḷus vai tos nepārzinot, lemjams būtu jautājums par mednieku kvalifikācijas diferencētu ieviešanu, regulārām mednieku apmācībām un regulāru zināšanu un prasmju pārbaudi. 
Inga Kudeikina. Medību tiesiskais regulējums medību drošības un sabiedrības interešu aspektā

Ne mazāk būtisks ir jautājums par medību ietekmi uz dabas resursu saglabāšanu. Saskañā ar Medību likuma 1. panta devìto punktu medību tiesības pieder zemes īpašniekam vai tiesiskajam valdītājam, kura īpašumā vai valdījumā esošajā zemes gabalā ietilpst medību platības [5], tātad medības notiek privātīpašumā esošos ìpašumos, kas prima face norāda uz to privāttiesisko raksturu, ar izrietošajām no tā iespējām brīvi, pēc saviem ieskatiem rīkoties ar ìpašumu. Un tomēr šāds traktējums nav pareizs, jo medību resursi ir nepieciešami sabiedrībai kopumā. Nevar noliegt, ka medījamo dzīvnieku skaits un veselības stāvoklis atstāj būtisku iespaidu uz ikviena indivīda tiesībām dzìvot kvalitatīvā vidē. Tiesības uz labvēlīgu vidi ir pamattiesības, tāpēc "valsts aizsargā ikviena tiesības dzìvot labvēlīgā vidē, sniedzot ziṇas par vides stāvokli un rūpējoties par tās saglabāšanu un uzlabošanu" [13]. Šajā aspektā medību tiesiskais regulējums iekḷaujas vides tiesību struktūrā.

Aizsardzības mehānisms ir paredzēts Medību likumā, nosakot, ka medību resursi ir izmantojami, nodrošinot to ilgtspējīgu apsaimniekošanu, proti, drīkst veikt "medījamo dzīvnieku populācijas un apdzīvotās vides un ar to saistīto dabas resursu apsaimniekošanu tādā veidā, lai saglabātu medību resursu biolog̣isko daudzveidību un atjaunošanās spēju, nodrošinot medību resursus nākamajām paaudzēm, kā arī veicinātu medījamo dzīvnieku aizsardzību, ņemot vērā saimnieciskās, sociālās un vides intereses un neapdraudot dabas aizsardzības pasākumu īstenošanu medījamo dzīvnieku sugu izplatības teritorijā" [5].

Tādējādi medību tiesību īpašnieks tiek ierobežots savu īpašuma tiesību realizēšanā un viņam ir uzlikti pienākumi dabas resursu apsaimniekošanā ievērot noteiktus principus un prasības. Sabiedrības interešu ievērošana, izlietojot īpašuma tiesību, vienmēr rada jautājumu par ierobežojumu samērīgumu. Literatūrā norādīts: "Privātā īpašuma ilgtspējīga attīstība ir atkarīga no kopienas (sabiedrības) pastāvīgas piekrišanas privātīpašuma institūtam, jo kopienas akcepts aizsargā gan pašu kopienu, gan privātīpašnieku, plašāk nodrošinot cilvēku labklājību. Priekšplānā izvirzās jautājumi par to, ka īpašuma tiesībām vajadzētu attīstīties šādu vērtību virzienā: autonomija, efektivitāte, stabilitāte, cilvēcība, vienlīdzība." [14; 1] Jāpiekrīt, ka privātīpašuma attīstība un izmantošana, ievērojot sabiedrības, arī šaurākā nozīmē, piemēram, konkrēta reǵiona vai pašvaldības iedzìvotāju, vajadzības, atstāj pozitīvu iespaidu arī uz īpašnieka tiesībām, saglabājot sociālo stabilitāti. Protams, jāṇem vērā, ka ierobežojumiem jābūt leg̣itīmiem, objektīvi nepieciešamiem un vienlīdzịgiem visiem tiesību subjektiem. Šajā sakarā jāatsaucas uz Latvijas Universitātes Juridiskās fakultātes Civiltiesisko zinātṇu katedras docētājas S. Meieres teikto: "Atbilstoši prevencijas logiikai ievērojami efektīvāku vides aizsardzību iespējams isstenot tad, ja vides izmantošanas regulējums ir noteikts nevis vispārīgi, bet gan maksimāli ievērojot noteiktas saimnieciskas darbības (projekta) parametrus, kā arī apstākḷus katrā konkrētā saimnieciskās darbības (projekta) istenošanas vietā." $[15 ; 88]$

Medību aspektā aizsardzības līdzeklis ir medījamo dzīvnieku iedalījums limitētajos, proti, medījamo dzīvnieku skaits ir ierobežots, piemēram, aḷni, lūši, medṇi, un 
nelimitētajos, kas nozīmē, ka medījamo dzīvnieku skaits nav ierobežots, piemēram, pelēkie zaḳi, āpši, fazāni. Limitēto dzīvnieku medīšanai ir noteikti vieni medību terminini, nelimitētajiem dzīvniekiem - citi [8]. Dabas aizsardzības entuziasti vairākkārt ir aicinājuši aizliegt medības. Tā, piemēram, Eiropas Parlamentā 2014. gadā tika iesniegti lūgumraksti par ùdensputnu medību aizliegšanu un par medību aizliegšanu vispār [16]. Autore pievienojas Eiropas Parlamenta viedoklim, ka nav pamata aizliegt medības vispār, jo "ilgtspējīgām medībām var būt pozitīva ietekme, palīdzot sasniegt saglabāšanas mērḳus attiecībā uz sugām un dzīvotnēm, piemēram, kontrolējot invazīvas sugas un plēsējus, kas var apdraudēt sugas, kuras aizsargā dabas direktīvas, un medniekiem veicot pozitīvas darbības attiecībā uz dabisko dzīvotṇu apsaimniekošanu" [16]. Vienlaikus jāuzsver, ka tas iespējams, precīzi un godprātīgi ievērojot tiesību aktus, kas reglamentē medības.

\section{Secinājumi}

Tiesību akti medību drošỉbas un vides ilgtspējīgas attīstības aspektā ir vērtējami pozitīvi. Lai arī tajos medību principi nav izteikti rakstveidā, tomēr tie iegūstami interpretācijas cel̦ā, proti, autore izšḳir šādus medību principus: medību saimniecība tiek organizēta, ievērojot ilgtspēju un sugu biologiiskās daudzveidības saglabāšanu, nosakot diferencētu pieeju medijjamajiem dzìvniekiem, iesaistot medniekus lēmumu pien̦emšanā, ievērojot sabiedrības intereses, medībās izmantojot tādus ieročus un rīkus, kas nepiel̦auj cietsirdīgu vai nežēlīgu izturēšanos pret medỉjamiem dzīvniekiem. Tiesiskais regulējums medību drošības jautājumiem nenoliedzami pievērš pietiekamu uzmanību, un jāatzīst, ka mednieku un trešo personu, tostarp sabiedrības kopumā, intereses ir sabalansētas.

Tomēr nelaimes gadījumi medībās un sabiedrības daļas negatīvā attieksme pret medībām liek uzdot jautājumu par tiesiskā regulējuma efektivitāti. Problēmas pamatā ir medību tiesiskā un faktiskā daba. Drošu un likumīgu medību garants ir mednieks, viña prasmes, zināšanas un gatavība precīzi ievērot Medību likuma, Medību noteikumu un citu saistošo tiesību aktu prasības. Tādējādi līdzeklis situācijas uzlabošanai ir mednieka profesionālās kvalitātes paaugstināšana. Tas sasniedzams vairāku kompleksu pasākumu realizēšanas ceḷā. Autore ierosina:

1) noteikt minimālo un maksimālo vecumu mednieka apliecības iegūšanai, piemēram, kā minimālo vecumu nosakot 21 gadu, bet maksimālo - 60 gadus;

2) noteikt obligātu personas veselības stāvokḷa izvērtējumu pirms mednieka apliecības sañemšanas;

3) paredzēt medniekiem regulāras kvalifikācijas un veselības stāvokḷa pārbaudes, piemēram, reizi piecos gados;

4) par medību noteikumu pārkāpšanu kā papildsodu noteikt mednieka apliecības anulēšanu un tiesību nodarboties ar medībām atṇemšanu uz laiku, piemēram, no viena līdz pieciem gadiem. 


\section{Hunting Legislation from Viewpoint of Hunting Safety and Public Interest}

\section{Abstract}

Hunting has long ceased to be a necessary means for survival. However, hunting has its fixed place in social life. In spite of the private nature of hunting, the need for special hunting legislation arises from several aspects associated with public interest. First, hunting involves an increased risk because of the use of hunting firearms and special devices, which implies special safety requirements. Second, hunting can be interpreted as interference with fauna, affecting the balance of nature, which therefore calls for a legal framework dealing with the place, time and means of hunting and game to be selected for this purpose. The objective of the article is to analyse two aspects of hunting legislation, which are essential for society, and namely hunting safety and public interest related to environmental protection in the hunting area.

The author concludes that the existing legal framework sufficiently deals with hunting safety and that the interests of hunters and third parties, including society in general, are well-balanced. Safe and lawful hunting is guaranteed by the hunter, hunter's skills, knowledge and readiness to comply with the requirements laid down in the Hunting Law, the Hunting Regulation and other binding laws and regulations. Hence, the existing situation could be improved by enhancing the professional quality of hunters. This could be achieved by means of a set of measures. The author suggests that the issuance of hunting licences could be subject to more stringent requirements and the annulment of a hunting licence could be applied as an extra penalty for infringements of hunting regulations.

Keywords: hunting, hunting safety, hunting licence, hunting regulations.

\section{Literatūra}

1. Medības ir dzìves veids. Latvijas Mednieku asociācija. Iegūts no: http://www.latma.lv/lv/ medibas-latvija/ [sk. 11.11.2015.].

2. Komerclikums. Latvijas Republikas likums, pieṇemts 13.04.2000., stājās spēkā 01.01.2002. Latvijas Vēstnesis, 158/160, 04.05.2000..

3. Baumanis, J. Pārnadžu (artiodactyla) populāciju stāvokḷa novērtējums un apsaimniekošanas principi Latvijā. Promocijas darba kopsavilkums. Iegūts no: http://llufb.llu.lv/dissertationsummary/forest_zoology/JanisBaumanis_prom_darba_kopsavilkums_2013_LLU_MF.pdf [sk. 12.11.2015.].

4. Likumprojekta Medību likums anotācija. Iegūts no: http://www.saeima.lv/bi8/ lasa?dd=LP0243_0 [sk. 11.11.2015.].

5. Medību likums: Latvijas Republikas likums, pieṇemts 08.07.2003., stājās spēkā 06.08.2003. Latvijas Vēstnesis, 107, 23.07.2003. 
Inga Kudeikina. Medību tiesiskais regulējums medību drošības un sabiedrības interešu aspektā

6. Missouri Wildlife Code. Iegūts no: http://www.sos.mo.gov/adrules/csr/current/3csr/3csr.asp [sk. 12.11.2015.].

7. Ieroču un speciālo līdzekḷu aprites likums: Latvijas Republikas likums, pienememts 28.10.2010., stājās spēkā 01.01.2011. Latvijas Vēstnesis, 183, 17.11.2010.

8. Medību noteikumi: LR Ministru kabineta 2014. gada 22. jūlija noteikumi Nr. 421., stājās spēkā 01.08.2014. Latvijas Vēstnesis, 150, 01.08.2014.

9. Administratīvo pārkāpumu kodekss: Latvijas Republikas likums, pieṇemts 07.12.1984., stājas spēkā 01.07.1985. Ziṇotājs, 51, 20.12.1984.

10. Krimināllikums: Latvijas Republikas likums, pieṇemts 17.06.1998., stājās spēkā 01.04.1999. Latvijas Vēstnesis, 199/200, 08.07.1998.

11. Spilgts. Elektroniskā vārdnīca Tezaurs. Iegūts no: http://tezaurs.lv/\#/sv/spilgts [sk. 11.11.2015.].

12. Administratìvās apgabaltiesas 24.05.2013. spriedums lietã Nr. 142131711. Iegūts no: http:// www.12d.lv/v.php?i=12503 [sk. 13.11.2015.].

13. Latvijas Republikas Satversme: Latvijas Republikas likums, pieñemts 15.02.1922., stājās spēkā 07.11.1922. Latvijas Vēstnesis, 43, 01.07.1993.

14. Byrne, J. P. The Public Nature of Property Rights and the Property Nature of Public Law. The Public Nature of Private Property. Ed. by Malloy, R. P., Diamond, M. Farnham, Surrey, England; Burlington, VT: Ashgate, 2011.

15. Meiere, S. Vides aizsardzības principu tiesiskais raksturs un to ievērošana lēmumu pieṇemšanā. Aktuālās tiesību realizācijas problēmas: Latvijas Universitātes 69. konferences rakstu krājums. Rīga: Latvijas Universitātes Akadēmiskais apgāds, 2011.

16. Eiropas Parlamenta 30.03.2015. Pazinojums Komitejas locekliem. Iegūts no: http://www. europarl.europa.eu/meetdocs/2014_2019/documents/peti/cm/1056/1056128/1056128lv.pdf [sk. 23.11.2015.]. 